\title{
Some Metabolic Differences Between Thiobacillus thioparus, T. denitrificans and T. thiocyanoxidans
}

\author{
By D. WOOLLEY, G. L. JONES AND F. C. HAPPOLD \\ Department of Biochemistry, The University of Leeds
}

(Received 22 January 1962)

\begin{abstract}
SUMMARY
Differences in behaviour of Thiobacillus thioparus, $T$. denitrificans and $T$. thiocyanoxidans were found in growth experiments carried out in thiosulphate or thiocyanate containing media and using aerobic or anaerobic conditions. These differences were: $T$. denitrificans and $T$. thioparus grew anaerobically in thiosulphate + nitrate and thiocyanate + nitrate media; T. thiocyanoxidans did not. During growth of T. thioparus in thiocyanate + nitrate medium, nitrite accumulated but thiocyanate was not completely oxidized; no nitrite accumulated during growth of $T$. denitrificans under similar conditions. After aerobic, serial subculture in thiosulphate medium $T$. denitrificans no longer grew anaerobically in thiosulphate + nitrate or thiocyanate + nitrate media whereas $T$. thioparus did. $T$. thioparus produced copious growth on thiosulphate agar slopes under aerobic conditions; $\boldsymbol{T}$. denitrificans proved difficult to culture under such conditions, i.e. there was a failure to guarantee growth on each occasion, and where growth occurred this was poor. $T$. denitrificans did not produce the mucoid slime associated with $T$. thioparus cultures. $T$. thioparus accumulated and subsequently used up tetrathionate during aerobic growth in thiosulphate medium; $T$. denitrificans did not.
\end{abstract}

\section{INTRODUCTION}

De Kruyff, Van der Walt \& Schwartz (1957) claimed, as a result of growth experiments, that under anaerobic conditions in thiosulphate + nitrate or in thiocyanate + nitrate media Thiobacillus denitrificans reduced nitrate to nitrogen but that $T$. thioparus and $T$. thiocyanoxidans reduced nitrate only to nitrite. They suggested, moreover, that the two latter organisms were metabolically identical. Happold, Jones \& Pratt (1958) agreed that T. thioparus and T. thiocyanoxidans grew similarly at the expense of thiocyanate under aerobic conditions. Pratt (1958) showed that $T$. thioparus cultures accumulated polythionates at an earlier stage of growth than was the case with $T$. thiocyanoxidans cultures, grown aerobically in thiosulphate medium. Jones \& Happold (1961), in confirming Pratt's results, showed that oxidation of the polythionates was potassium ion dependent. We have consequently attempted to define further the similarities and dissimilarities between these organisms. Vishniac \& Santer (1957) stated that $\boldsymbol{T}$. denitrificans 'differed from $T$. thioparus only in ability to grow under anaerobic conditions with nitrate as terminal respiratory electron acceptor, and that $\boldsymbol{T}$. denitrificans could grow aerobically in absence of nitrate in thiosulphate medium but rapidly lost denitrifying ability on aerobic subculture, thus becoming indistinguishable from $T$. thioparus'. The experiments reported in the present paper were designed to resolve the apparent 
difference in the views of the above authors, namely, that de Kruyff et al. (1957) could grow $T$. thioparus anaerobically but that Vishniac \& Santer (1957) could not, and to obtain information which might be used in differentiating between the three species of Thiobacillus used here.

\section{METHODS}

Organisms. The initial culture of Thiobacillus denitrificans was obtained from Dr K. S. Baalsrud, and was subcultured weekly in screw-capped bottles completely filled with the liquid thiosulphate + nitrate medium of Baalsrud \& Baalsrud (1954).

The culture of Thiobacillus thiocyanoxidans used was developed from a single cell isolated from a crude culture which oxidized thiocyanate.

The initial culture of Thiobacillus thioparus was obtained from the National Collection of Industrial Bacteria (NCIB 8370) described as 'Starkey's original non-motile strain'. From this culture a single colony on a thiosulphate agar plate was picked, grown and used for subculture.

The $T$. thiocyanoxidans and $T$. thioparus cultures were subcultured weekly on thiosulphate agar slopes.

Media. For anaerobic cultures the thiosulphate + nitrate medium of Baalsrud \& Baalsrud (1954) and thiocyanate + nitrate medium of de Kruyff et al. (1957) were used. For aerobic cultures the thiosulphate medium described by Jones \& Happold (1961) was used; thiosulphate agar was prepared according to these authors.

Estimations. Thiosulphate was estimated by titration with iodine according to Vogel (1951); polythionate by titration with iodine after treatment with $\mathrm{KOH}$ according to Starkey $(1934 b)$; thiocyanate spectrophotometrically by a modification of the method described by Bowler (1944); nitrite spectrophotometrically by the method of Rider \& Mellon (1946). To estimate nitrate in presence of nitrate advantage was taken of the observation of Skerman, Lack \& Millis (1951) that nitrate and nitrite yielded the same colour when determined spectrophotometrically by the brucine method of Noll (1945), and that with mixtures of nitrate and nitrite the colour densities were additive. Thus it was possible to estimate the nitrate concentration in a mixture of nitrate + nitrite when the concentration of nitrite had been determined by the method of Rider \& Mellon (1946). None of the other ions of the concentrations found in the media used affected any of these estimations.

Chromatography. The methods of Jones \& Happold (1961) for detecting polythionates were used. Potassium pentathionate prepared by the method of Goehring \& Feldmann (1948) was used as an additional marker.

\section{RESULTS}

\section{Anaerobic cultures}

Thiobacillus denitrificans and T. thioparus grew anaerobically in both nitratecontaining media; $T$. thiocyanoxidans did not. These results contrast with those of de Kruyff et al. (1957) who reported growth of $T$. thiocyanoxidans anaerobically in both nitrate-containing media, and with the statement of Vishniac \& Santer (1957) that ' $T$. thioparus was a strictly aerobic bacterium'. Figures $1 a$ and $1 b$ show the thiocyanate, nitrate and nitrite concentrations measured during growth of $T$. denitrificans and $T$. thioparus in screw-capped bottles completely filled with thio- 
cyanate + nitrate medium. With $T$. thioparus nitrite accumulated and thiocyanate was not completely used up. These facts may be associated, for the rate of thiocyanate utilization decreased when the nitrite concentration reached $150 \mu \mathrm{g} . / \mathrm{ml}$. and ceased when the nitrite concentration was $200 \mu \mathrm{g} . / \mathrm{ml}$. The decrease in rate and subsequent cessation of thiocyanate utilization by Thiobacillus thioparus in thiocyanate + nitrate medium may have been related to nitrite concentration; inhibitory concentrations of nitrite for growth of thiobacilli have been shown as follows: $1 \times 10^{-2} \mathrm{M}-\mathrm{NO}_{2}$ and $1 \cdot 4 \times 10^{-2} \mathrm{M}-\mathrm{NO}_{2}$ for anaerobic growth of $T$. denitrificans in thiosulphate + nitrate and thiocyanate + nitrate media respectively (Baalsrud \& Baalsrud, 1954; Woolley, 1961); $2.1 \times 10^{-2} \mathrm{M}^{-N_{2}}$ for aerobic growth of $T$. thioparus

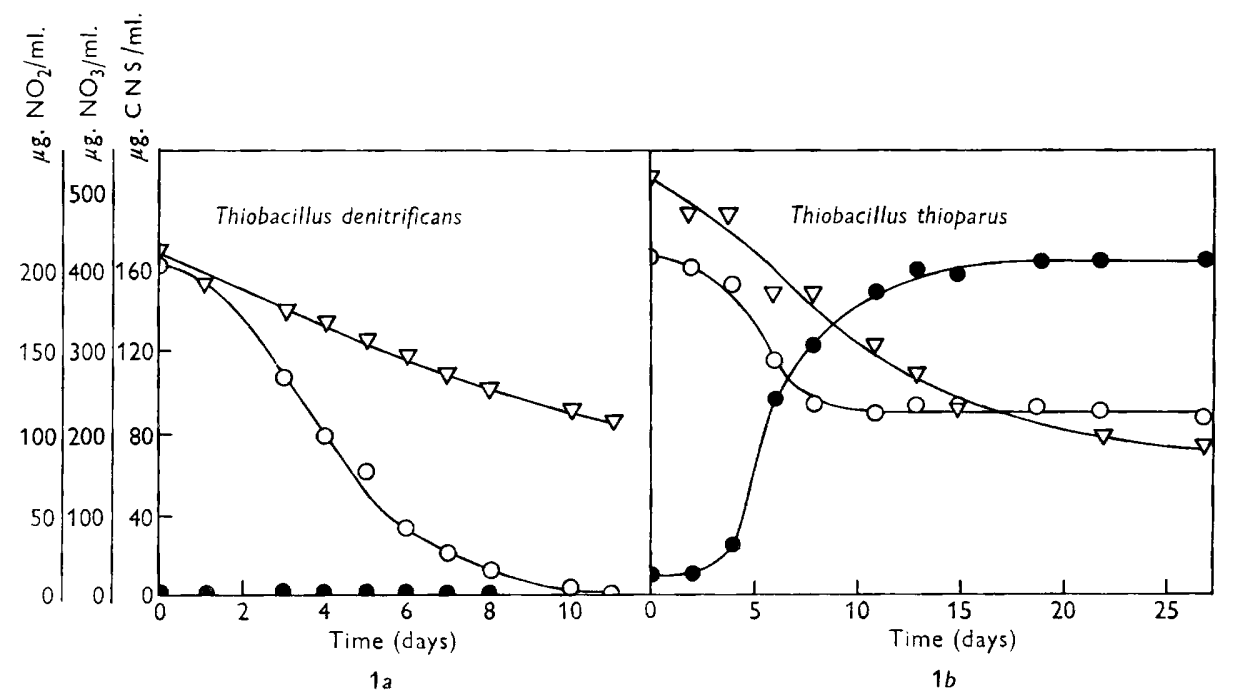

Fig. 1 $a$. Utilization of thiocyanate $\bigcirc$, and nitrate $\nabla$ and production of nitrite $\bullet$ by a culture of Thiobacillus denitrificans.

Fig. 1b. Utilization of thiocyanate $O$, and nitrate $\nabla$ and production of nitrite $\bullet$ by a culture of Thiobacillus thioparus.

in thiosulphate medium (Starkey, $1934 a) ; 1 \cdot 4 \times 10^{-3} \mathrm{M}-\mathrm{NO}_{2}$ for aerobic growth of T. thiocyanoxidans in thiocyanate medium (Youatt, 1953). No quantitative comparisons were made of the anaerobic growth of $T$. denitrificans and $T$. thioparus in thiosulphate + nitrate medium because of difficulties associated with the estimations of thiosulphate and nitrite in the presence of each other.

\section{Aerobic cultures}

After aerobic, serial subculture in the thiosulphate medium of Jones \& Happold (1961), $T$. denitrificans no longer grew anaerobically when inoculated into thiosulphate + nitrate or thiocyanate + nitrate media, whereas $T$. thioparus which before such subculture has been maintained aerobically, grew immediately under anaerobic conditions in nitrate-containing media.

Whereas Thiobacillus thioparus needed 24-48 hr. to produce copious growth on thiosulphate agar slopes under aerobic conditions, $T$. denitrificans proved extremely 
difficult to grow on thiosulphate agar under aerobic or anaerobic conditions; minute white colonies took between nine and seventeen days to appear under these conditions. $T$. denitrificans did not produce the mucoid slime associated with $T$. thioparus cultures; cultures of the latter organism took appreciably longer to filter because they were mucoid.

Figures $2 a$ and $2 b$ show $\mathrm{pH}$ values and thiosulphate and polythionate concentrations in $50 \mathrm{ml}$. cultures of the two organisms grown in $250 \mathrm{ml}$. conical flasks containing thiosulphate medium (Jones \& Happold, 1961). Differences between the organisms

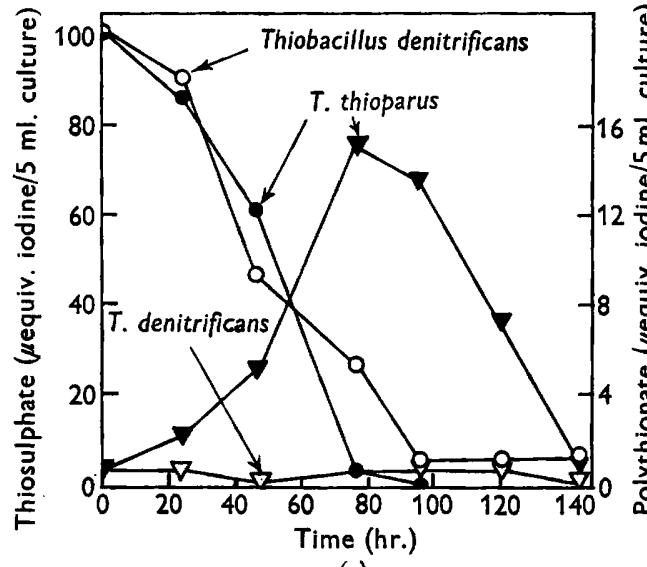

(a)

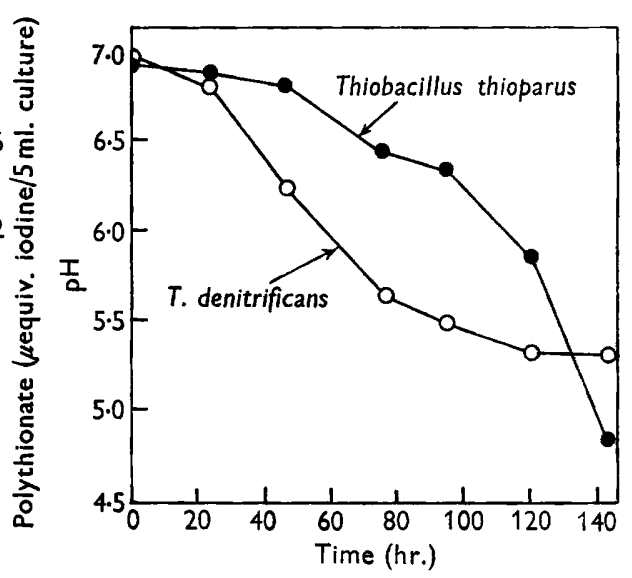

(b)

Fig. 2a. Utilization of thiosulphate by Thiobacillus denitrificans $\bigcirc$ and by $T$. thioparus ; production of polythionate by Thiobacillus denitrificans $\nabla$ and by $T$. thioparus $\nabla$.

Fig. 2b. Acid production during culture of Thiobacillus denitrificans $\bigcirc$ and T. thioparus 9.

Table 1. Utilization of thiosulphate and production of polythionate by Thiobacillus thioparus and $T$. denitrificans

\begin{tabular}{|c|c|c|c|c|c|c|c|c|}
\hline \multirow{3}{*}{$\begin{array}{c}\text { Time } \\
\text { (days) }\end{array}$} & \multicolumn{4}{|c|}{ Medium $a$} & \multicolumn{4}{|c|}{ Medium $b$} \\
\hline & \multicolumn{2}{|c|}{ T. thioparus } & \multicolumn{2}{|c|}{$T$. denitrificans } & \multicolumn{2}{|c|}{ T. thioparus } & \multicolumn{2}{|c|}{ T. denitrificans } \\
\hline & $\mathrm{S}_{2} \mathrm{O}_{3}$ & $\mathbf{P}$ & $\mathrm{S}_{2} \mathrm{O}_{3}$ & $\mathbf{P}$ & $\mathrm{S}_{2} \mathrm{O}_{3}$ & $\mathbf{P}$ & $\mathrm{S}_{2} \mathrm{O}_{3}$ & $\mathbf{P}$ \\
\hline 0 & $187 \cdot 5$ & $\mathbf{2 \cdot 5}$ & 190 & $\mathbf{3} \cdot \mathbf{0}$ & $93 \cdot 5$ & 1.5 & 91.5 & 0.5 \\
\hline 1 & $186 \cdot 5$ & $0 \cdot 5$ & $192 \cdot 5$ & $2 \cdot 3$ & 88.5 & $3 \cdot 0$ & 91 & 0.5 \\
\hline 2 & 180 & $3 \cdot 5$ & 189.5 & $6 \cdot 0$ & 83 & - & 83 & $\mathbf{2 \cdot 5}$ \\
\hline 3 & 176 & 6.0 & $182 \cdot 5$ & $1 \cdot 5$ & 76 & $7 \cdot 0$ & 72 & $\mathbf{2 \cdot 0}$ \\
\hline 4 & 169.5 & 9.5 & 175.5 & $2 \cdot 5$ & $70 \cdot 5$ & $8 \cdot 0$ & 66 & 0.5 \\
\hline 5 & 164 & $13 \cdot 5$ & $171 \cdot 5$ & 1.5 & $59 \cdot 5$ & 15 & $59 \cdot 5$ & $1 \cdot 0$ \\
\hline 7 & 150 & $26 \cdot 0$ & 156.5 & $\mathbf{1 . 5}$ & 40 & $24 \cdot 5$ & 44.-5 & 0 \\
\hline $\boldsymbol{9}$ & 133.5 & $\mathbf{3 3} \cdot \mathbf{0}$ & 143 & $4 \cdot 0$ & $24 \cdot 5$ & $80 \cdot 5$ & $32 \cdot 5$ & 0 \\
\hline 11 & 114.5 & $41 \cdot 0$ & 130 & $1 \cdot 0$ & $\mathbf{5} \cdot \mathbf{5}$ & 89 & $18 \cdot 5$ & $\mathbf{0}$ \\
\hline 14 & $76 \cdot 0$ & $59 \cdot 0$ & 108 & $17 \cdot 5$ & $\mathbf{0}$ & $21 \cdot 5$ & 16 & 0 \\
\hline 15 & - & 一 & - & - & 0 & 20 & - & - \\
\hline 21 & $\mathbf{0}$ & 30.0 & 49.5 & 36.5 & 0 & 19 & $13 \cdot 5$ & 0.5 \\
\hline
\end{tabular}

Medium $a$ : thiosulphate $\left(\mathrm{S}_{2} \mathrm{O}_{3}\right)$ of Jones \& Happold (1961).

Medium $b$ : thiosulphate of Baalsrud \& Baalsrud (1954), omitting nitrate.

$\boldsymbol{P}=$ polythionate.

Concentrations expressed as $\mu$ equiv, $I_{2} / 5 \mathrm{ml}$. culture. 
can be seen (Fig. 2) in respect of polythionate production and rate of acid production. Table 1 shows differences in the amounts of titratable polythionate produced by the two organisms during growth of $500 \mathrm{ml}$. cultures in 1 l. flasks. The media used were: $a$ that described by Jones \& Happold (1961); $b$ that described by Baalsrud \& Baalsrud (1954) but without nitrate. During the latter experiment concentrates of culture filtrates were chromatographed on paper to detect polythionates; Table 2 shows some differences between the two organisms with respect to the polythionates which accumulated.

Table 2. Chromatographic detection of polythionates in culture filtrate concentrates from cultures of Thiobacillus denitrificans and T. thioparus

\begin{tabular}{|c|c|c|c|c|c|}
\hline \multirow{2}{*}{$\begin{array}{c}\text { Time } \\
\text { (days) }\end{array}$} & \multirow{2}{*}{ Medium } & \multirow{2}{*}{ Organism } & \multicolumn{3}{|c|}{ Polythionates } \\
\hline & & & $\mathrm{S}_{3} \mathrm{O}_{6}$ & $\mathrm{~S}_{4} \mathrm{O}_{6}$ & $\mathbf{S}_{5} \mathrm{O}_{6}$ \\
\hline 14 & $\begin{array}{l}a, \mathrm{~S}_{2} \mathrm{O}_{3} \text { (Jones \& } \\
\mathrm{Happold,} \mathrm{1961)} \\
b, \mathrm{~S}_{2} \mathrm{O}_{3}: \text { no } \mathrm{NO}_{3} \\
\text { (Baalsrud \& Baals- } \\
\text { rud, 1954) }\end{array}$ & $\begin{array}{l}\text { T. thioparus } \\
T . \text { denitrificans } \\
T \text {. thioparus } \\
T \text {. denitrificans }\end{array}$ & $\begin{array}{l}+ \\
+ \\
+ \\
-\end{array}$ & $\begin{array}{l}- \\
- \\
-\end{array}$ & $\begin{array}{l}+ \\
+ \\
+ \\
-\end{array}$ \\
\hline 21 & $\begin{array}{l}a \\
b\end{array}$ & $\begin{array}{l}\text { T. thioparus } \\
T . \text { denitrificans } \\
T . \text { thioparus } \\
T . \text { denitrificans }\end{array}$ & $\begin{array}{l}+ \\
+ \\
? \\
-\end{array}$ & $\begin{array}{l}+ \\
+ \\
+ \\
?\end{array}$ & $\begin{array}{l}? \\
+ \\
+ \\
-\end{array}$ \\
\hline
\end{tabular}

The strains of Thiobacillus denitrificans and $T$. thioparus used here were capable of anaerobic growth in the presence of nitrate at the expense of thiosulphate or thiocyanate. In contrast to the report of de Kruyff et al. (1957), our T. thiocyanoxidans did not grow anaerobically in thiosulphate + nitrate or thiocyanate + nitrate media. In contrast to the statements of Vishniac \& Santer (1957) our cultures of $T$. denitrificans and $T$. thioparus were easily distinguished when grown aerobically (as indicated above). Of the differences described, we attach most weight to the loss of capacity for anaerobic growth by $T$. denitrificans in thiosulphate + nitrate or thiocyanate + nitrate media after aerobic subculture, and to the production of slime by the non-motile strain of $\boldsymbol{T}$. thioparus. The differences observed with respect to rate of acid production and polythionate production may have been of degree only for, as Jones \& Happold (1961) showed, the type of polythionate which accumulated in cultures of $T$. thioparus was altered by changing the sodium:potassium ion ratio of the growth medium. Furthermore, we found manometrically (Woolley, 1961) that the oxidation of potassium tetrathionate by washed whole cell suspensions of $T$. denitrificans proceeded at different rates according to the sodium: potassium ion ratio of the buffers used to suspend the organisms. 


\section{REFERENCES}

BaAlsrud, K. \& BaAlsrud, K. S. (1954). Studies on Thiobacillus denitrificans. Arch. Mikrobiol. 20, 34.

Bowler, R. G. (1944). The determination of thiocyanate in blood serum. Biochem. J. 38, 385.

De Kruyff, C. D., van der Walt, J. P. \& Schwartz, H. M. (1957). The utilization of thiocyanate and nitrate by Thiobacilli. Antonie van Leeurenhoek J. Microbiol. Serol. 23, 305.

GoeHring, M. \& Feldmann, U. (1948). Neue Verfahren zur Darstellung von Kaliumpentathionat und von Kaliumhexathionat. $Z$. anorg. Chem. 257, 223.

Happold, F. C., Jones, G. L. \& Pratt, D. B. (1958). Utilization of thiocyanate by Thiobacillus thioparus and T. thiocyanoxidans. Nature, Lond. 182, 266.

JoNEs, G. L. \& HAPPOLD, F. C. (1961). The occurrence of polythionates as intermediates in the metabolism of thiosulphate by the Thiobacilli. J. gen. Microbiol. 26, 361 .

Nour, C. A. (1945). Determination of nitrate in boiler water by the brucine reagent. Industr. Engng Chem. (Anal.), 17, 426.

Pratt, D. B. (1958). Detection of polythionate in cultures of Thiobacilli by means of the Folin-Ciocalteu Reagent. Nature, Lond. 181, 1075.

Rrder, B. F. \& Mellon, M. G. (1946). Colorimetric determination of nitrites. Industr. Engng Chem. (Anal.), 18, 96.

Skerman, V. B. D., LACK, J. \& Mrrurs, N. (1951). Influence of oxygen concentration on the reduction of nitrate by a Pseudomonas sp. in the growing culture. Aust. J. sci. Res. Series B, 4, 511.

Starkey, R. L. (1934a). Cultivation of organisms concerned in the oxidation of thiosulphate. J. Bact. 28, 365.

StaRKey, R. L. $(\mathbf{1 9 3 4} b)$. The production of polythionates from thiosulphate by microorganisms. J. Bact. $28,387$.

Vishniac, W. \& Santer, M. (1957). The Thiobacilli. Bact. Rev. 21, 195.

Vogex, A. I. (1951). A Textbook of Quantitative Inorganic Analysis. Theory and Practice, 2nd ed. London: Longmans, Green and Co.

Woollex, D. (1961). The biochemistry of Thiobacillus denitrificans. Ph.D. thesis: University of Leeds.

Youat, J. B. (1953). The breakdown of thiocyanate by microorganisms. Ph.D. thesis: University of Leeds. 